\title{
EFFECT OF ORGANIC FERTILIZATION ON THE QUANTITY AND QUALITY OF MELON PRODUCTION
}

\author{
Maria Dinu' ${ }^{1}$, Rodica Soare ${ }^{2 *}$, Cristina Băbeanu ${ }^{3}$, Gheorghița Hoza ${ }^{4}$, \\ Alexandru Ioan Apahidean ${ }^{5}$
}

\author{
${ }^{1}$ University of Craiova, Faculty of Horticulture, Department of Horticulture \& Food Science, 20058, Craiova, \\ Romania \\ ${ }^{2}$ University of Craiova, Faculty of Agriculture, Department of Agricultural and Forestry Technologies, 200333, \\ Craiova, Romania \\ ${ }^{3}$ University of Craiova, Faculty of Sciences, Department of Chemistry, 200478, Craiova, Romania, \\ ${ }^{4}$ University of Agronomic Sciences and Veterinary Medicine of Bucharest, Faculty of Horticulture, Department \\ of Bioengineering of Horticultural systems, 011464 Bucharest, Romania \\ ${ }^{5}$ University of Agricultural Sciences and Veterinary Medicine Cluj-Napoca, Faculty of Horticulture, Department \\ II Forestry, 400372, Cluj-Napoca, Romania, \\ *soarerodi@yahoo.com
}

https://doi.org/10.34302/crpjfst/2019.11.2.14

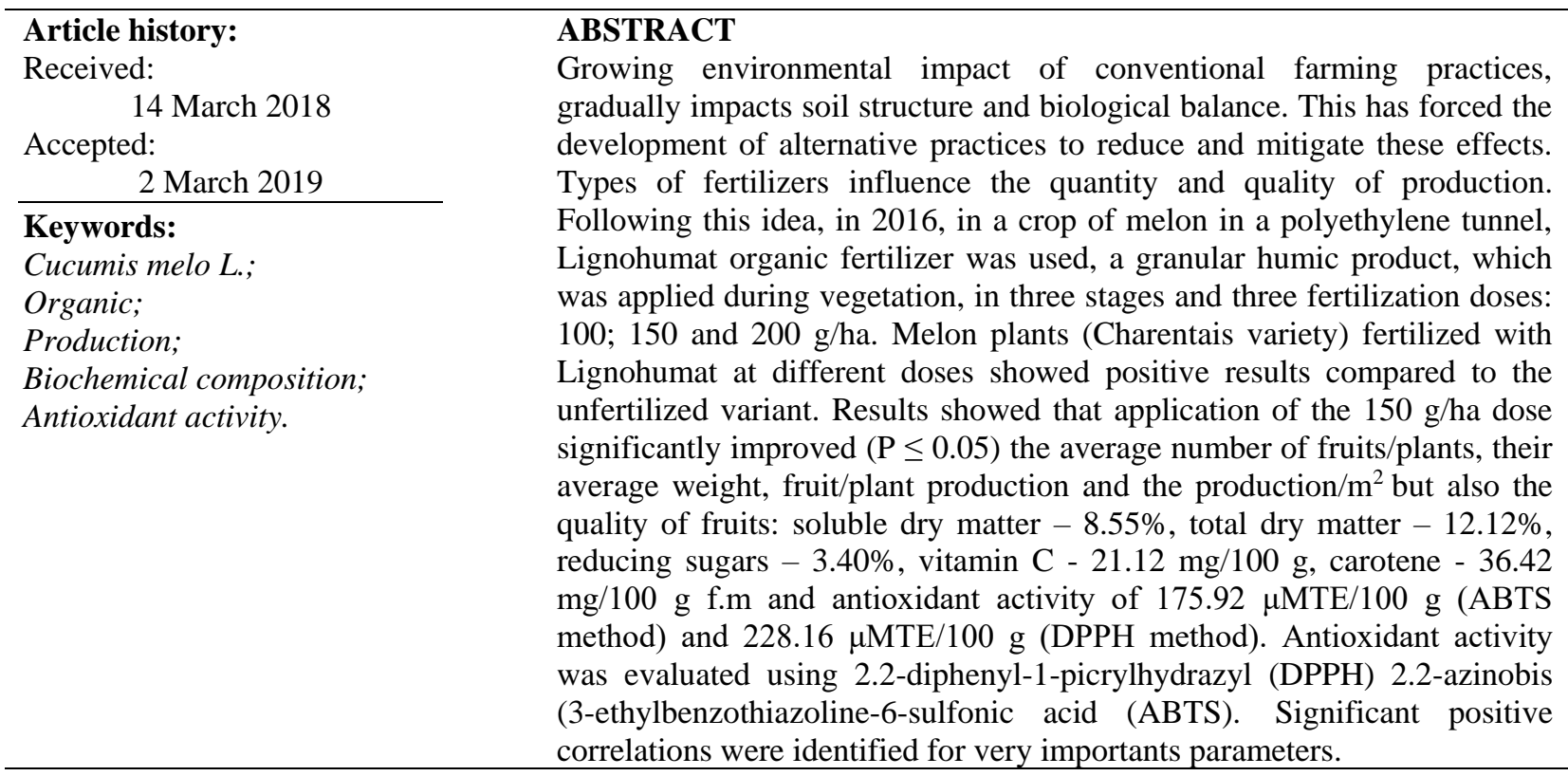

\section{Introduction}

High demand for agricultural products in order to obtain food and consumer goods in modern society has generated significant increases in agrarian activities over the past decades. Consequently, it has been necessary to implement methods that will, among other things, improve crop efficiency, mitigate the negative impact on soil, reduce the use of chemical fertilizers and increase crops economic return. 
Organic fertilization involves use of organic fertilizers, decomposition of organic matter debris, use of domestic waste water, manure and microorganisms (fungi and bacteria) (Chirinos et al., 2006). In recent years, lignocellulosic materials have been used as fiber raw materials in the production of biodegradable nutrient pots for vegetable seedlings in containers. Considering the high degradation potential of these materials, they can also be used as sources of biofertilizers (Nechita et al., 2010).

All these are used to improve nutrient fixation in the rhizosphere, to produce growth stimulators for plants, to improve soil stability by ensuring effective biological control, and promote micorization, symbiosis and bioremediation in soils contaminated with toxic substances (Rivera-Cruz et al., 2008).

Bio-fertilizer application improves surface productivity in a relatively short time, reduces soil and water contamination, increases soil fertility, thus promoting antagonism and biological control of phytopathogenic organisms (Chirinos et al., 2006). These issues provide real benefits for farmers as a result of lower fertilization costs and higher yields. Implementation of fertilization techniques requires feasibility studies, monitoring of environmental variables involved in metabolic processes, capital investment, time and trained personnel (Vanegas, 2003).

Biofertilizers have a significant effect on production due to nutrients that mobilize microorganisms that contribute to the availability of macro and micro elements and their forms (El-Sanafawi, 2006, Ahmed and Fraihat, 2011). Application of biofertilizers improves plant growth morphological elements, chlorophyll content and $\mathrm{N}, \mathrm{P}, \mathrm{K}$ elements, production elements (weight and number of fruit/plant) and quality (Dinu et al., 2013). Therefore, the purpose of this study was to evaluate Lignohumat organic fertilizer based on humic acids on quantitative and qualitative elements of melon fruit and to establish an optimal dose for a polyethylene tunnel culture, thus reducing the negative impact on soil and environment. Cucumis melo L. culture was chosen to diversify the diet and because melon fruits are also a significant source of polyphenol antioxidant phytochemicals which provide health benefits, especially to the cardiovascular system, as largely shown for other foods.

\section{Materials and methods}

\subsection{Plant material}

Experience was placed in a polyethylene tunnel of the Faculty of Horticulture and Agriculture (University of Craiova), Romania. Biological material was represented by Charentais variety. The experience had four variants and was placed in randomized blocks in three rehearsals. Variant specifics were as follows: $V_{1}$ (Control) - unfertilized; $V_{2-}$ fertilized with Lignohumat $100 \mathrm{~g} / \mathrm{ha} ; \mathrm{V}_{3-}$ fertilized with Lignohumat $150 \mathrm{~g} / \mathrm{ha}$; $\mathrm{V}_{4}$ fertilized with Lignohumat $200 \mathrm{~g} / \mathrm{ha}$. Culture was set up by planting on 03.05.2016 according to the following technological scheme: $50+$ $110(3)+50 \times 30 \mathrm{~cm}\left(3.2 \mathrm{pl} / \mathrm{m}^{2}\right)$.

Lignohumat organic fertilizer was applied foliarly at 10 days interval. Lignohumat is a highly effective humic product with chelating microelements with growth stimulating effect and plant protection against stress. Prior to the establishment of the crop, agrofond was given 30 t/ha of composted grape marc. Culture technology was that specific to yellow melons grown in polyethylene tunnels.

\subsubsection{Samples preparation}

A quantity of $100 \mathrm{~g}$ of each sample was broken up with a blender. 1 gram of homogenized sample (pulp) was mixed with 10 $\mathrm{ml} 80 \%$ methanol, intensely agitated for 10 minutes using a vortex. Extraction of phenolic compounds was carried out by keeping the mixture in an ultrasonic bath for 70 minutes. The mixture was filtered, and to the solid residue was added $5 \mathrm{ml}$ of $80 \%$ methanol and the extraction procedure repeated. The two obtained extracts were combined and analyzed 
using protocols specific work to determine the total polyphenol and antioxidant capacity.

2.2.Soluble dry matter (S.D.M) content was determined gravimetrically and the result was espressed in percentages.

2.3.The soluble solids content (SSC) \% was determined using a digital refractometer (Kruss Optronic DR 301-95) from the juice pressed from the fruit the result was espressed in percentages.

2.4.The titratable acid content (acidity) was determined by titration with $0.1 \mathrm{~N}$ sodium hydroxide $(\mathrm{NaOH})$ and expressed as \% citric acid.

2.5.Carbohydrates (reducing sugars) $(\%)$ were extracted in distilled water $(1: 50 \mathrm{w} / \mathrm{V})$ and assayed colorimetric with 3.5 dinitrosalicylic acid using glucose as standard. Ascorbic acid was extracted in 3\% metaphosphoric acid (1:50 $\mathrm{w} / \mathrm{V})$ and determined by using redox titration with 2,6-dichloroindophenol.

\subsection{The determination of total carotenoids}

The weighed samples, having been put separately in $95 \%$ in acetone $(50 \mathrm{ml}$ for each gram), were homogenized with Braun MR 404 Plus for one minute. The homogenate was filtered and was centrifuged using the Hettich Universal 320/320R centrifuge at $2500 \mathrm{rpm}$ for ten minutes. The supernatant was separated and the absorbances were read at $400-700 \mathrm{~nm}$ on Cary 50 spectrophotometer. It was recorded that Chlorophyll a showed the maximum absorbance at $662 \mathrm{~nm}$, chlorophyll b at $646 \mathrm{~nm}$ and total caroten at $470 \mathrm{~nm}$. The value of these pigments was calculated using the method described by Dinu et al., (2013).

\subsection{Total phenolic content}

The amount of total phenolic compounds in the leaf and petiol of sweet potato extract was determined colorimetrically with FolinCiocalteu reagent by using the method described by Singleton and Rossi (1965) with some modifications. To $1 \mathrm{ml}$ extracts (diluted 1:10 with ultrapure water), $1 \mathrm{ml}$ bidistilled water (blank), $1 \mathrm{ml}$ of each standard solution were introduced in laboratory flasks of $25 \mathrm{ml}$ and added every $5 \mathrm{ml}$ reactive Folin-Ciocalteu (diluted 1:10 with ultrapure water). After 2 min, $4 \mathrm{ml}$ of sodium carbonate solution $7.5 \%$ was added and they were kept in the incubator during $2 \mathrm{~h}$ at the room's temperature.

The absorbance was measured at $765 \mathrm{~nm}$ by using a model evolution 600, double beam scanning UV-visible spectro-photometer, PC control with VISION pro software. A standard curve was prepared by using 50, 100, 150, 200 and $250 \mathrm{mg} / \mathrm{L}$ solutions of gallic acid in methanol and water $(60: 40, \mathrm{v} / \mathrm{v})$. Gallic acid was used as the reference standard and the results (total phenolic content) were expressed as gallic acid equivalents (GAE) and the results were expressed as mg/g F.W.

\subsection{Antioxidant activity}

Extracts for the determination of antioxidant activity were prepared into $80 \%$ aqueous methanol $(1: 10 \mathrm{w} / \mathrm{v})$ at $24^{\circ} \mathrm{C}$ for $16 \mathrm{~h}$. The resulting slurries were centrifuged at $4000 \mathrm{~g}$ for $5 \mathrm{~min}$ and the supernatants were collected. The total phenolics content was determined colorimetric by using the Folin-Ciocalteu reagent (Dinu et al., 2016) and expressed as mg of gallic acid equivalents (GAE)/100g f.w. The capacity of extracts to reduce the radical 2,2diphenyl-1-picrylhydrazyl was assessed colorimetric. The Trolox calibration curve was plotted as a function of the percentage of DPPH radical scavenging activity. The results were expressed as $\mu \mathrm{M}$ Trolox equivalents (TE)/100g.

The ABTS radical cation scavenging activity of the methanolic extract was assessed colorimetric. The final results were expressed as $\mu \mathrm{M}$ Trolox equivalents (TE)/100g fw.

\subsection{Statistical analisis.}

The significance of differences between variants was statistically determined using variance analysis using ANOVA and 
calculating the limit differences, $\mathrm{LSD} \leq 0.05 \%$, (LSD = least significant difference). The correlation coefficients between quality parameters were performed by multiple correlation coefficientes.

\section{Results and discussions}

\subsection{Production Determinations}

Production determinations in the experimental variants concerned the average number of fruits/plants, average weight/fruit, production/plant and production $/ \mathrm{m}^{2}$.

Concerning the average fruit/plant number (Table 1), it varied from 5.4 to $\mathrm{V}_{1}$ to 7.2 at $\mathrm{V}_{3}$, the variant with significant results. Regarding the average weight/fruit this was higher in the fertilized variants compared to unfertilized variant, which shows that the fertilization dose directly influences production. Significant differences between variants are observed in production obtained per plant $\left(4.7 \mathrm{~kg}\right.$ per $\mathrm{V}_{3}$ versus $2.7 \mathrm{~kg}$ at $\mathrm{V}_{1}$ ) and production per $\mathrm{m}^{2}-15$ $\mathrm{kg} / \mathrm{m}^{2}$ at $\mathrm{V}_{3}$ versus $8.6 \mathrm{~kg} / \mathrm{m}^{2}$ at $\mathrm{V}_{1}$ unfertilized. Results are similar to those obtained by Mohamed and Mohamed (2016) in an experiment with fertilizer variants in melon culture, but also those reported by Adam et al., (2009) and Naidu et al., (2014).

\subsection{Biochemical determinations}

Main biochemical components of melon fruit are shown in Table 2. High content of soluble solids (SSC) corresponds to a good accumulation in sugars, which is very important from a sensory point of view. It was different at each variant. Highest content, of $8.55 \%$ was recorded at $\mathrm{V}_{3}$, followed by $\mathrm{V}_{2}$ and $\mathrm{V}_{4}$ and the lowest in $\mathrm{V}_{1}$, non-fertilized variant. Dry substance (\%) values recorded in this study confirm results of Ahmad and Al-Fraihat (2011). Total soluble dry matter had the highest value $(12.12 \%)$ in the fertilized variant with $150 \mathrm{~g} / \mathrm{ha}$ Lignohumat and the lowest in the unfertilized version (6.80\%). $\mathrm{V}_{2}$ and $\mathrm{V}_{4}$ had values close to each other but greater than $\mathrm{V}_{1}$ and much lower than $\mathrm{V}_{3}$ (Table 2). The total dry substance values $(\%)$ obtained in the study at the University of Craiova, Romania, are superior to those obtained by Mohamed and Mohamed (2016) in a study with several variants of fertilization of melons, one of which was compost + humic acids + microorganisms.

Table 1. Elements of production at studied variants

\begin{tabular}{|l|c|c|c|c|}
\hline Variant & $\begin{array}{c}\text { Average fruit/plant } \\
(\text { number })\end{array}$ & $\begin{array}{c}\text { Average weight / fruit } \\
(\mathrm{g})\end{array}$ & $\begin{array}{c}\text { Production/plantProduction. } \\
(\mathrm{kg})\end{array}$ & $\begin{array}{c}\mathrm{m}^{2} \\
(\mathrm{~kg})\end{array}$ \\
\hline $\mathrm{V}_{1}$ - control & $5.4^{\mathrm{b}}$ & $471^{\mathrm{b}}$ & $2.7^{\mathrm{c}}$ & $8.6^{\mathrm{c}}$ \\
\hline $\mathrm{V}_{2}$ & $6.0^{\mathrm{ab}}$ & $552^{\mathrm{ab}}$ & $3.5^{\mathrm{bc}}$ & $11.2^{\mathrm{b}}$ \\
\hline $\mathrm{V}_{3}$ & $7.2^{\mathrm{a}}$ & $643^{\mathrm{ab}}$ & $4.7^{\mathrm{a}}$ & $15.0^{\mathrm{a}}$ \\
\hline $\mathrm{V}_{4}$ & $6.4^{\mathrm{ab}}$ & $680^{\mathrm{a}}$ & $4.5^{\mathrm{ab}}$ & $14.4^{\mathrm{a}}$ \\
\hline $\mathrm{LSD} \leq 0.05$ & 1.2 & 180.4 & 1.1 & 1.8 \\
\hline
\end{tabular}

The different letters in the same row indicate significant differences $\mathrm{P} \leq 0.05$ between the variants

Table 2. Biochemical determinations of melon fruits

\begin{tabular}{|l|c|c|c|c|c|}
\hline \multicolumn{1}{|c|}{ Variant } & $\begin{array}{c}\text { Soluble } \\
\text { solids (\%) }\end{array}$ & $\begin{array}{c}\text { Soluble dry matter } \\
(\%)\end{array}$ & $\begin{array}{c}\text { Acidity (citric } \\
\text { acid \%) }\end{array}$ & $\begin{array}{c}\text { Carbohydrates } \\
(\%)\end{array}$ & $\begin{array}{c}\text { Vitamin C } \\
(\mathrm{mg} / 100 \mathrm{~g} \text { f.m.) }\end{array}$ \\
\hline $\mathrm{V}_{1-\text { c control }}$ & $5.80^{\mathrm{c}}$ & $6.80^{\mathrm{d}}$ & $0.085^{\mathrm{d}}$ & $2.75^{\mathrm{b}}$ & $16.88^{\mathrm{c}}$ \\
\hline $\mathrm{V}_{2}$ & $7.25^{\mathrm{b}}$ & $8.29^{\mathrm{c}}$ & $0.105^{\mathrm{c}}$ & $2.66^{\mathrm{b}}$ & $20.10^{\mathrm{b}}$ \\
\hline $\mathrm{V}_{3}$ & $8.55^{\mathrm{a}}$ & $12.12^{\mathrm{a}}$ & $0.147^{\mathrm{a}}$ & $3.40^{\mathrm{a}}$ & $21.12^{\mathrm{a}}$ \\
\hline $\mathrm{V}_{4}$ & $7.05^{\mathrm{b}}$ & $8.91^{\mathrm{b}}$ & $0.133^{\mathrm{b}}$ & $3.01^{\mathrm{a}}$ & $19.40^{\mathrm{b}}$ \\
\hline $\mathrm{LSD} \leq 0.05$ & 0.944 & 0.514 & 0.008 & 0.451 & 0.887 \\
\hline
\end{tabular}

The different letters in the same row indicate significant differences $\mathrm{P} \leq 0.05$ between the variants 
Acidity recorded low levels ranging from 0.085 to $0.147 \%$ citric acid in melon fruit on experimental variants. The highest content was recorded at variant fertilized with $150 \mathrm{~g} / \mathrm{ha}$ Lignohumat $(0.147 \%)$, still small quantities compared to other fruit or vegetable species. These values are also supported by Kolayli et al., (2010) and Obando-Ulloa et al., (2009). Carbohydrates, an important parameter for determining fruit quality, ranged from $2.66 \%$ to $\mathrm{V}_{2}$ to $3.40 \%$ at $\mathrm{V}_{3}$ with statistically significant differences for $\mathrm{V}_{3}$ and $\mathrm{V}_{4}$ variants that were fertilized with the highest doses of Lignohumat. Lingle and Dunlap (1987) stated that sugary melons are influenced by environmental factors. Thus, climatic factors, fertilization regime and nature of fertilizer influence the content in sugars, and implicitly the quality of the fruit. Vitamin $\mathrm{C}$ is a very important natural antioxidant. Its biological importance is based on the ability to participate in various enzymatic processes, hydroxylation, oxidationreduction. Vegetable vitamin $\mathrm{C}$ content may vary depending on environmental factors and stress, such as: light intensity, temperature, humidity, pollution (Dinu et al., 2016). The values in Table 2 for vitamin $\mathrm{C}$ content ranged between $16.88 \mathrm{mg} / 100 \mathrm{~g}$ f.m. in unfertilized variant and $21.12 \mathrm{mg} / 100 \mathrm{~g}$ f.m. in the fertilized variant with $150 \mathrm{~g} / \mathrm{ha}$ of Lignohumat. The determined values are similar to those in literature. Thus, Laster and Hodges, (2008), in a study of three melon varieties, determined an ascorbic acid content of $34.7-44.7 \mathrm{mg} / 100 \mathrm{~g}$. Obando-Ulloa et al., (2009) reported an ascorbic acid content, determined at 29 melon isogenic lines from 6.0 to $19.7 \mathrm{mg} / 100 \mathrm{~g}$. Highest values of ascorbic acid were determined for melon varieties followed by grafted melons and the lowest values for hybrids. Laster and Hodges, (2008) stated that culture technology directly influences the accumulation of ascorbic acid in melon varieties.

Total polyphenols represent the largest class of secondary metabolites in plants. Phenolic content and composition of fruits and vegetables depend on genetics, environmental conditions, and storage conditions after harvest. Table 3 presents the values of total melanin fruit polyphenols for the experimental variants. It is noted that the highest content was recorded in variant 3 of $94.10 \mathrm{mg}$ GAE/100 g f.m followed by $\mathrm{V}_{4}$ with $40.65 \mathrm{mg}$ GAE/100 g f.m. Variance analysis highlighted variant 3. The results of our study are superior to those obtained by Preciado-Rangel et al., (2015) in a melon culture treated with different types of organic fertilizers. They claim that low nitrogen, magnesium and phosphorus content in organic fertilizers could cause nutritional stress in melon plants during growth, thus favoring the increase in phenolic compounds.

Carotenoids are one of the main lipophilic constituents, which contribute to total antioxidant activity and to content of provitamin in potato but also in other vegetals (Lachman et al., 2016). Variance analysis for total carotene content showed a significant difference $(\mathrm{P}<0.05)$ between studied variants. Results show a variation from $24.96 \mathrm{mg} / 100 \mathrm{~g}$ f.m to $V_{1}$ to $36.32 \mathrm{mg} / 100 \mathrm{~g}$ f.m to $\mathrm{V}_{3}$. Highest value was at $V_{3}$, fertilized with $150 \mathrm{~g} / \mathrm{ha}$ of Lignohumat, followed by $\mathrm{V}_{4}$ and $\mathrm{V}_{2}$. High values and differences between variants may be the result of different fertilizer doses and orange pulp color (Charentais variety) and are also supported by Henan et al., (2013).

Results of this study are similar to those obtained by Woblang et al., (2010), which studied the influence of pre and post-harvest factors on $\beta$-carotene content and antioxidant capacity of melon. In the present study, values greater than $31 \mathrm{mg} / 100 \mathrm{~g}$ f.m are the differentiated result from fertilization dose. Menon and Ramana Rao, (2012) reported values of carotene content close to those of this study, their research being focused on melon plants nutrition at various stages of ripening.

Evaluation of antioxidant activity is a parameter for assessing nutritional quality. DPPH radicals are generally used as a screening method for evaluating a wide variety of compounds. Antioxidant activity of the 
studied variants was determined by the ability of the extracts to reduce the ABTS radical cation. It had values between 103.30 $\mu \mathrm{MTE} / 100 \mathrm{~g}$ f.m to $\mathrm{V}_{2}$ and $175.92 \mu \mathrm{MTE} / 100 \mathrm{~g}$ f.m to $\mathrm{V}_{3}$. DPPH method varied between 104.0 $\mu \mathrm{MTE} / 100 \mathrm{~g}$ f.m at unfertilized variant and $228.16 \mu \mathrm{MTE} / 100 \mathrm{~g}$ f.m at variant fertilized with $150 \mathrm{~g} / \mathrm{ha}$ of Lignohumat. From the results it can be said that the fertilizer dose of $150 \mathrm{~g} / \mathrm{ha}$ has significantly influenced antioxidant activity of melons. Other doses did not influence antioxidant activity compared to non-fertilized variant.

Table 3. Biochemical determinations of melon fruit

\begin{tabular}{|l|l|l|l|l|}
\hline \multirow{2}{*}{ Varianta } & \multirow{1}{*}{$\begin{array}{c}\text { Total phenolics } \\
\text { content* } \\
\end{array}$} & \multirow{2}{*}{$\begin{array}{c}\text { Total carotene } \\
(\mathrm{mg} \text { GAE/100g f.m. }\end{array}$} & & \multicolumn{2}{|c|}{ Antioxidant activity } \\
\cline { 4 - 5 } & & & $\begin{array}{l}\text { ABTS } \\
(\mu \mathrm{MTE} * * / 100 \mathrm{~g} \text { f.m. })\end{array}$ & $\begin{array}{l}\text { DPPH } \\
(\mu \mathrm{MTE} * * / 100 \mathrm{~g} \\
\text { f.m. })\end{array}$ \\
\hline V1-Control & $34.76^{\mathrm{c}}$ & $24.96^{\mathrm{c}}$ & $123.00^{\mathrm{b}}$ & $104.3^{\mathrm{b}}$ \\
\hline V2 & $36.90^{\mathrm{c}}$ & $31.28^{\mathrm{b}}$ & $103.32^{\mathrm{b}}$ & $112.0^{\mathrm{b}}$ \\
\hline V3 & $94.10^{\mathrm{a}}$ & $36,42^{\mathrm{a}}$ & $175.92^{\mathrm{a}}$ & $228.1^{\mathrm{a}}$ \\
\hline V4 & $40.65^{\mathrm{b}}$ & $31,52^{\mathrm{b}}$ & $134.09^{\mathrm{b}}$ & $107.5^{\mathrm{b}}$ \\
\hline LSD $\leq 0.05$ & 2,44 & 1,62 & 36,7 & 39,42 \\
\hline
\end{tabular}

*gallic acid equivalents; ** equivalents Trolox; The different letters in the same row indicate significant differences $\mathrm{P} \leq 0.05$ between the variants

Table 4. Correlations between the biochemical compounds analyzed in the melon variants fertilized with Lignohumat

\begin{tabular}{|c|c|c|c|c|c|c|c|}
\hline Specification & $\begin{array}{l}\text { S.S.M } \\
\left({ }^{0} \mathrm{Bx}\right)\end{array}$ & $\begin{array}{l}\text { S.D.M } \\
(\%)\end{array}$ & $\begin{array}{l}\text { Carbo- } \\
\text { hydrates } \\
(\%)\end{array}$ & $\begin{array}{l}\text { Total } \\
\text { phenolics } \\
\text { content mg } \\
\text { (GAE/100g } \\
\text { f.m }\end{array}$ & $\begin{array}{l}\begin{array}{l}\text { Total } \\
\text { caroten } \\
(\mathrm{mg} / 100 \mathrm{~g}\end{array} \\
\text { f.m.) }\end{array}$ & $\begin{array}{l}\text { Antioxidant } \\
\text { activity } \\
\text { ABTS } \\
(\mu \mathrm{MTE} / 100 \mathrm{~g} \\
\text { f.m) }\end{array}$ & $\begin{array}{l}\text { Antioxidant } \\
\text { activity } \\
\text { DPPH } \\
(\mu \mathrm{MTE} / 100 \mathrm{~g} \\
\text { f.m) }\end{array}$ \\
\hline $\begin{array}{l}\text { Vitamin C (mg/100g } \\
\text { f.m) }\end{array}$ & $0.936 * * *$ & $0.856^{* * * *}$ & $0.598^{*}$ & $0.682^{*}$ & $0.972^{* * * *}$ & 0.471 & $0.679 *$ \\
\hline S.S.M $\left({ }^{0} \mathrm{Bx}\right)$ & - & $0.960^{* * *}$ & $0.771 * *$ & $0.853 * * *$ & $0.994 * * *$ & $0.680 *$ & $0.847 * * *$ \\
\hline S.D.M (\%) & - & - & $0.915^{* * * *}$ & $0.946^{* * *}$ & $0.950 * * *$ & $0.857^{* * * *}$ & $0.930^{* * * *}$ \\
\hline $\begin{array}{l}\text { Carbohydrates } \\
(\%) \\
(\%)\end{array}$ & - & - & - & $0.922 * * *$ & $0.767^{* * *}$ & $0.982 * * *$ & $0.885^{* * *}$ \\
\hline $\begin{array}{l}\text { Total phenolics conten } \\
\text { (mg GAE/100g f.m) }\end{array}$ & - & - & - & - & $0.812^{* *}$ & $0.924 * * *$ & $0.996 * * *$ \\
\hline $\begin{array}{l}\text { Total carotene } \\
\text { (mg/100 g f.m.) }\end{array}$ & - & - & - & - & - & $0,660^{*}$ & $0,799 * *$ \\
\hline
\end{tabular}

Variation of antioxidant potential depends on plant maturity stage or analyzed plant parts, genotype, culture method, environmental conditions (Soare et al., 2016) but also of the fertilizers used, therefore, Preciado-Rangel et al., (2015). recommend fertilization with organic nutrients applied foliar to melon culture to improve the nutritional qualities of production.

Antioxidant activity begins to increase with the onset of fruit maturation, reaches a peak in the ripening stage, after which it decreases at overmaturation (data not shown). Although all four variants of melon were grown under same 
environmental conditions, study results show that $150 \mathrm{~g} / \mathrm{ha}$ Lignohumat dose significantly influenced the production elements as well as biochemical characteristics of melon fruit, thus there were significant differences between unfertilized variant and $V_{3}$. The correlations between certain quality parameters of melon fruit obtained in the fertilized experience with different doses of Lignohumat are presented in the table 4 . For the majority of the parameters, significant positive correlations were identified. Literature confirms that when fruits and vegetables with high carotene content are consumed, there is a strong antioxidant activity in the body because there is a strong correlation between these two elements.

Corrigan et al., 2000 support the view that pumpkin fruits with a high sugar content and high total carotenoids are considered to be good quality fruits and can be eaten raw.

\section{Conclusions}

Our results have shown that the use of the Lignohumat natural fertilizer in three different doses at melon culture in polyethylene tunnel has led to the production of qualitative and quantitative yields superior to the unfertilized control. The average number of fruit/plant (7.2), average fruit weight (643 g) and average yield $/ \mathrm{m}^{2}\left(15 \mathrm{~kg} / \mathrm{m}^{2}\right)$ were recorded at $\mathrm{V}_{3}(150$ $\mathrm{g} / \mathrm{ha})$. Also in this variant, the organoleptic properties of melon fruit recorded the highest values compared to the non fertilized control but also with the other two variants fertilized with different doses.

Significant positive correlations were registered between all parameters studied regardless of the fertilization dose. These results may recommend the use of Lignohumat $150 \mathrm{~g} / \mathrm{ha}$ for the fertilization of some vegetable crops in the polyethylene tunnel, knowing that in the vegetable sector, due to the superintensive character, high doses of fertilizers can be used which can cause soil and groundwater pollution. Organic fertilization with Lignohumat is a viable alternative to a source of organic nutrients in order to obtain melon productions grown in the polyethylene tunnel with superior nutraceutical qualities.

\section{References}

Adam, S.M., Abdalla, A.M., Risk, F.A. (2002). Effect of the interaction between the mineral and bio-fertilizer on the productivity of cantaloupe (Cucumis melo L.) under the newly reclaimed soils conditions. Egyptian Journal of Horticulture, 29 (2), 301-315.

Ahmad, H., Al-Fraihat. (2011). Effect of mineral nitrogen and biofertilizer on the productivity and quality of melon plants in South Ghor Area, Jordan. International Journal of Current Research, 33 (6), 295303.

Chirinos, J., Leal, A., Montilla, J. (2006). Uso de insumos biológicos como alternativa para la agricultura sostenible en la zona sur del Estado Anzoátegui. Revista Digital Ceniap Hoy, 11,1-7.

Corrigan, V., Irving, D.E., Potter, F.J. (2000). Sugarsand sweetness in buttercup squash. Food Quality and Preference, (11), 313322.

Dinu, M., Soare, R., Hoza, G., Becherescu, A.D. (2016). Biochemical Composition of Some Local Pumpkin Population. Agriculture and Agricultural Science Procedia, 10, 185-191.

Dinu, M., Dumitru, M.G., Pintilie, I. (2013). Comparative Study of Certain Hot Pepper Genotypes (Capsicum annuum L.) Cultivated in Oltenia, România. (IJSR) International Journal of Scientific Research, 2(7), 54-57.

Dinu, M., Soare, R., Dumitru, M.D. (2013). Effect of the humic acids and their combination with boron and polyphenols extracted from the seeds of vitis vinifera to culture of tomatoes in solar. Annals of the University of Craiova, Serias Biology, Horticulture, Food Produce Processing, Technology, Environmental Engineering, 1, 157-163. 
El-Sanafawi, E.M. (2006). Effect of some biofertilizers ongrowth and productivity of cucumber plants growth under plastic house conditions. Mansoura Univity Journal of Agricultural Sciences, 31(1), 393-400.

Henan, I., Tlili, I., Ilahy, R., Rhim,T., Jebari, H. (2013). Evaluation of Qualitative Parametersand Physicochemical Properties of Local Varieties of Muskmelon (Cucumis melo L.) Grown in Tunisia, Food 7 Global Science Books, 17-23.

Kolayli, S., Kara, M., Ulusoy, E., Tezcan, F., Erim, F.B., Aliyazicioglu, R. (2010). Comparative study of chemical and biochemical properties of different melon cultivars: Standard, hybrid, and grafted melons. Journal of Agricultural Food and Chemistry, 58, 9764-9769.

Lachman, J., Hamouz, K., Orsák, M., Kotíková, Z. (2016). Carotenoids in potatoes-a short overview. Plant Soil Environ, 62(10), 474481.

Lingle, S.E., Dunlap, J.R. (1987). Sucrose metabolism in netted muskmelon fruit during development. Plant Physiology, 84, 386- 389.

Menon, S.V., Ramana Rao, T.V. (2012). Nutritional quality of muskmelon fruit as revealed by its biochemical properties during different rates of ripening. International Food Research Journal, 19(4), 1621-1628.

Mohamed, M.H.M., Maha-Mohamed, E.A. (2016). Effect of Some Organic and Bio Fertilization Treatments in Presence of Chemical Fertilization on Growth, Chemical Composition and Productivity of Cantaloupe Plants. International Journal of Plant \& Soil Science, 11(1), 1-11.

Naidu, Y., Meon, S., Siddiqui, Y. (2014). Foliar application of microbial-enriched compost tea enhances growth, yield and quality of muskmelon (Cucumis melo L.) cultivated under fertigation system. Scientia Horticulturae, 159,33-40.

Nechita, P., Dobrin, E., Ciolacu, F., Bobu, E., (2010).The biodegradability and mechanical strength of nutritive pots for vegetable planting based on lignocellulose composite materials. BioResources, 5(2): 1102-1113.

Obando-Ulloa, J.M., Eduardo, I., Monforte ,A.J., Trujillo, P.F. (2009). Identification of QTLs related to sugar and organic acid composition in melon using near-isogenic lines. Scientia Horticulturae, 121, 425-433.

Preciado-Rangel, P., Garcia-Villela, K.M., Fortis-Hernandez, M....Esparza-Rivera, J. (2015). Nutraceutical quality of cantaloupe melon fruits produced under fertilization with organic nutrient solutions. Ciencia $e$ investigacion agraria, 42(3), 475-481.

Rivera-Cruz, M., Trujillo, A., Córdova, G., Kohler, J., Caravaca, F., Roldán, A. (2008). Poultry manure and banana waste are effective bio-fertilizer carriers for promoting plant growth and soil sustainability in banana crops. Soil Biology \& Biochemistry, 40(12), 3092-3095.

Soare, R., Dinu, M., Băbeanu, C., Fortofoiu M. (2016). Bioactive compounds and antioxidant capacity in some genotypes of white cabbage (Brassica Oleracea var. capitata f. alba). SGEM- Conference Proceedings, (Nano, bio and greentechnologies for a sustenaible future 1(6), 437-444.

Singleton, V.L., Rossi, J.A. (1965). Colorimetry of total phenolics with phosphomolybdic-phosphotungstic acid reagents. American Journal of Enology and Viticulture, 16, 144-158.

Vanegas, R. (2003). La transición: la búsqueda del cambio hacia sistemas sustentables de producción agropecuria. Foro Agrario „Sistemas Agricolas Sustenables”.Quito: Universidad Central del Ecuador, 18-19. 